Pak. j. sci. ind. res. Ser. B: biol. sci. 201356 (1) 11-17

\title{
Prospects of Using Gypsum to Conserve Water and Improve Wheat Yield in Rainfed Aridisols
}

\author{
Obaid Ur Rehman ${ }^{\mathrm{a}}$, Muhammad Rashid ${ }^{\mathrm{a} *}$, Sarosh Alvi ${ }^{\mathrm{b}}$, Rahina Kausar ${ }^{\mathrm{a}}$, \\ Rizwan Khalid ${ }^{\mathrm{b}}$ and Tanvir Iqbal ${ }^{\mathrm{c}}$ \\ ${ }^{a}$ Soil and Water Conservation Research Station Fateh Jang (Attock), Pakistan \\ bSoil and Water Testing Laboratory, Rawalpindi, Pakistan \\ 'PMAS-Arid Agriculture University, Rawalpindi, Pakistan
}

(received August 30, 2011; revised November 19, 2012; accepted November 27, 2012)

\begin{abstract}
A long term field study (2005-10) was carried out at the farmer's field to evaluate the residual effect of gypsum on soil moisture conservation and wheat production under rainfed conditions. The treatments included application of gypsum @ 0,1 and $2 \mathrm{t} / \mathrm{ha}$, and its comparison with farmer practice (F.P). The basal dose of fertilizers NPK was applied @ 120, 80, $60 \mathrm{~kg} /$ ha every year before the sowing of wheat. Soil samples were collected before the sowing of wheat every year for soil moisture determination. Gypsum application not only resulted in an increase in soil moisture contents (up to $41 \%$ ) but also improved grain yield up to $23 \%$ and straw yield up to $19 \%$. The effect of gypsum was noticeable during low rainfall years compared to control ( $0 \mathrm{t} / \mathrm{ha}$ gypsum). The results showed that the gypsum could be an effective additive for soil amendment, enhancing wheat yield in rainfed areas by conserving soil moisture and nutrients.
\end{abstract}

Keywords: gypsum, wheat, moisture, rainfed, soil moisturte

\section{Introduction}

The agricultural land in rainfed areas of Pakistan are characterized by many problems like uneven topography, soil and water erosion, nutrient deficiency and moisture shortage. Optimum conservation of rain water is key factor for the success of crops in rainfed areas. About $17 \%$ of the cultivated area depends on rainfall for crop production which is the major source of soil moisture for plants. There is large variation in the amount, distribution and intensity of rainfall. Generally two third of the rainfall is received during 'Monsoon' (July, August, and September). Loss of rain and irrigation water as run off and soil erosion by water leads to severe soil degradation problems. The resultant reduction in crop yield and decrease in soil productivity may eventually lead to desertification (Singer, 2000) and it is necessary to conserve this moisture by adopting suitable techniques for its use by succeeding crop. An optimum conservation of rain water is critical for successful crop productions in rainfed areas as water productivity and fertilizer use efficiency are directly linked with the rainfall and moisture in the root zone during plant growth. Efficient utilization of water and soil resources needs the adoption of appropriate water

*Author for correspondence; E-mail: rashid_hameedi@hotmail.com management practices (Rashid, 2004). In Pakistan 4.67 million hactare area is rainfed which solely depends on moisture received from precipitation but these areas are subjected to various degrees of erosion by wind and water. Consequently, the natural resources are on severe decline. Because of uneven terrain and erratic rainfall patterns about 6 million acre feet (maf) of water is lost annually (Chaudhry, 1996) while the rainfed area contributes only $10 \%$ of the total agricultural production.

Attock district is classified into sub-humid and semi arid areas and has gentle to steep topography (Shafiq et al., 2005). Soils of district Attock show scarcity regarding the organic matter and other essential nutrients required for plants as these soils are calcareous, high in reaction $(\mathrm{pH})$ and mostly light eroded. The undulating field conditions aggravate the problems like; soil erosion, moisture wastage, over wetness and drought through uneven water distribution in the soil (Shafiq et al., 1996). Run off from rainfall destroys the soil structure which needs soil and water conservation measures including gypsum addition for proper structure development for better infiltration and water holding capacity to intercept run off and avoid dispersion of soil (Shaheen et al., 2008). Wheat is cultivated on about 40,000 acres and average annual production of wheat is $800 \mathrm{~kg} /$ acre in Attock areas (AR, 2010). 
Traditional strategies for soil and water conservation include protecting the soil surface from raindrop impact, preventing seal formation and soil detachment and increasing surface depression storage and soil roughness to reduce run off volume and velocity. Use of mulch, organic materials, tillage and chemicals etc. are the standard practices/techniques to conserve the moisture in situ soil conditions. A variety of chemicals are also available that are able to conserve or help to conserve the precipitation but most of these are expensive. Gypsum $\left(\mathrm{CaSO}_{4} \cdot 2 \mathrm{H}_{2} \mathrm{O}\right)$ is abundantly used as a soil amendment most primarily because of its easy availability, low cost and its effectiveness to conserve soil moisture (Amezketa et al., 2003). Gypsum applied to the soil has the ability to minimize clay dispersion which then improves the permeability of the soil and stability of aggregates at the soil surface. Chemical amelioration of soil structure, particularly through application of gypsum, is widely reported. Shah et al. (2011) concluded that $1.25 \mathrm{t}$ gypsum/ha resulted in higher rate of return (wheat production) compared with $2.5 \mathrm{t}$ gypsum/ha on coarse textured soils under rainfed environment. Ahmad et al. (2009) reported a significant increase in concentration and uptake of major nutrients (NPK) by addition of gypsum in soil. The objective of this study was to evaluate the impact of gypsum on soil moisture conservation and on the yield of wheat under rainfed conditions.

\section{Materials and Methods}

Soil interpretations of the study area. Soils of study area are moderately deep, well drained, fine textured, calcareous with structural B horizon, developed in loess deposited during the late Pleistocene period. It occupies nearly level to gently sloping sub-recent eroded surfaces in level loess plains under a sub-humid sub-tropical continental climate. It has brown/ dark brown, silty clay loam, massive, moderately calcareous A horizon, underlain by a dark brown silty clay, weak medium and coarse sub-angular blocky, moderately calcareous, B horizon to about $58 \mathrm{~cm}$, underlain by a brown/dark brown faintly mottled, silty clay loam, massive, strongly calcareous C horizon (SSP, 1970).

Site and experiment. The research trials were conducted at the farmer's fields at Kharala-I, Kharala-II, (Fateh Jang) and Hafizabad-I, Hafizabad-II (Jand), district Attock (2005-2010) to evaluate the residual effect of different rates of gypsum applied to soil on wheat crop under rainfed conditions. The treatments included control (no gypsum), 1 and $2.0 \mathrm{t}$ gypsum/ha and a treatment comprising farmer practice. Farmer practice was based on use of FYM (1.0 t/ha once every 3 years) and urea (50 kg/ha/year), di-ammonium phosphate (DAP, $<50 \mathrm{~kg} /$ ha once every two or three years). The gypsum doses were incorporated into the soil by deep ploughing before the onset of monsoon in June, 2005. The basal dose of chemical fertilizers (NPK, $120,80,60 \mathrm{~kg} / \mathrm{ha}$ ) was applied every year before the wheat sowing in first three treatments. The sources of NPK were urea, DAP and sulphate of potash (SOP), respectively. Wheat variety Chakwal-97 was sown at the beginning of November every year. All the cultural practices were performed uniformly throughout the growing period of wheat, each year while the soil was left fallow in summer.

Climate. The area lies between elevations of 300-600 mm and has a mean annual rainfall of $350-650 \mathrm{~mm}$. The climate is semi-arid warm, sub-tropical winter/monsoon and falls under climax vegetation of dry sub-tropical broadleaved-thorn mixed forest, agro-ecological regionVI. The mean maximum temperature ranges up to $40{ }^{\circ} \mathrm{C}$ in May-June, while the mean minimum temperature ranges between $2.2-4.7^{\circ} \mathrm{C}$ during December and January (Ahmad et al., 2006).

Data collection. A composite soil sample $(0-15 \mathrm{~cm})$ was collected from each site before the application of treatments and at the end of the study and analyzed for various physico-chemical characteristics (Table 1). The trials were laid in randomized complete block design (RCBD) in triplicate with plot size $3 \mathrm{~m} \times 4 \mathrm{~m}$. For soil moisture contents, every year, a composite soil sample was collected from the depth of $0-15 \mathrm{~cm}$ and $15-30 \mathrm{~cm}$ from each plot before the sowing of wheat. Rainfall and temperature data was recorded at Meteorological Data Station of Soil and Water Conservation Research Station (SAWCRS), Fateh Jang (Figs. 1-2).

Chemical analysis. Soil samples were collected from $0-15 \mathrm{~cm}$ depth from all the study sites. All the soil analysis was carried out at SAWCRS, Fateh Jang. Soil $\mathrm{pH}$ and EC were determined by the methods described by McLean (1982) and Richards (1954), respectively. Soil organic matter was determined by the oxidation of soil with sulphuric acid and potassium dichromate (Walkley and Black, 1934). Ammonium acetate method was used for the determination of extractable $\mathrm{K}$ in soil (Rhoades, 1982) while soil P was determined by shaking soil with $\mathrm{NaHCO}_{3}$ (Watanabe and Olsen, 1965) and soil texture by Bouyoucus method. 


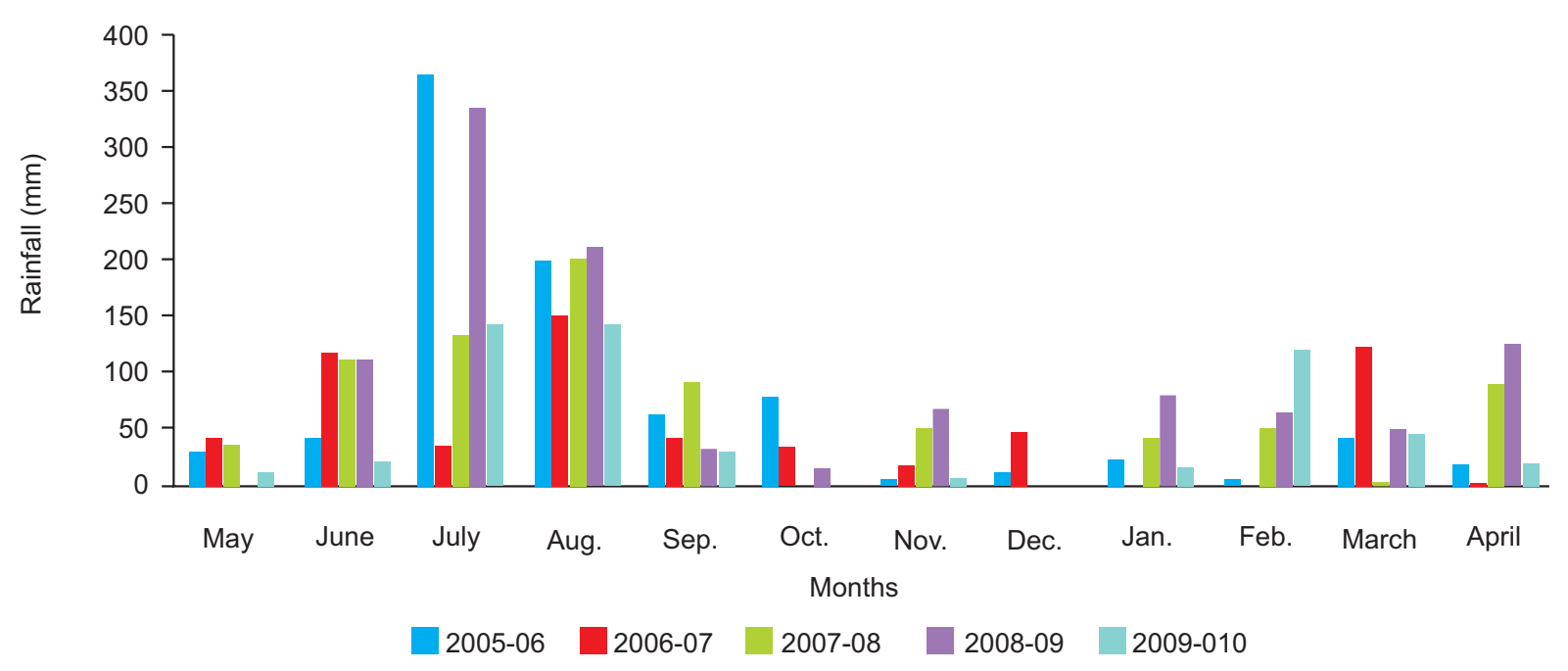

Fig. 1. Rainfall pattern in study area.

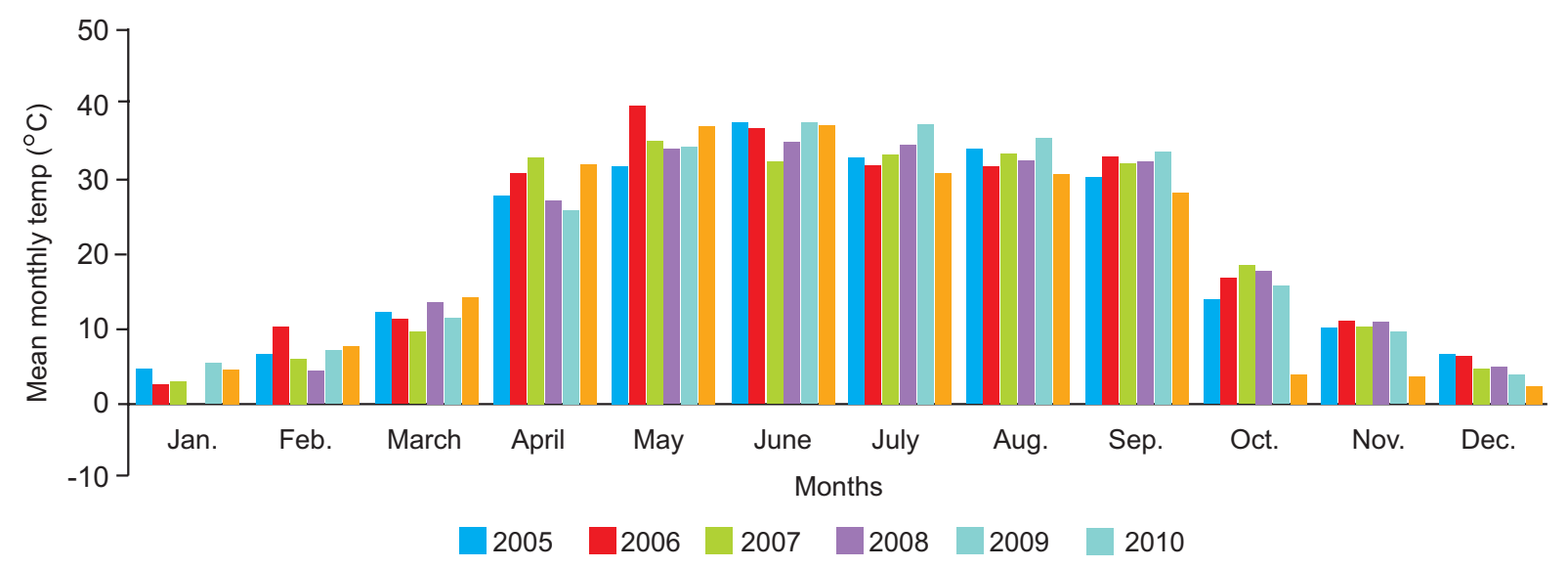

Fig. 2. Mean monthly temperature.

Statistical analysis. The collected data was statistically analyzed using methods described by Steel et al. (1997). MS Word \& Excel-2010 and M-Stat C computer software was used to compare the differences.

\section{Results and Discussion}

Results of the study have been discussed as under:

Wheat grain yield. The data regarding wheat grain yield has been presented in Fig. 3. The data indicated that an appreciable increase in the wheat grain yield compared to control was observed every year. Wheat grain yield during five years ranged from $1278 \mathrm{~kg} / \mathrm{ha}$ to $2868 \mathrm{~kg} / \mathrm{ha}$. The highest yield $(2868 \mathrm{~kg} / \mathrm{ha})$ was achieved in 2005-06 in $\mathrm{T}_{2}(1.0 \mathrm{t}$ gypsum/ha) followed by $2722 \mathrm{~kg} / \mathrm{ha}$ in $\mathrm{T}_{3}(2.0 \mathrm{t}$ gypsum/ha) which was 17 and $11 \%$ more compared with the control, respectively. Maximum percent increased (23\%) in grain yield was obtained in $\mathrm{T}_{2}$ (1.0 $\mathrm{t}$ gypsum/ha) in 2009-10 compared to control even though the least rainfall was received during this year. From 2005 to 2010 overall maximum grain yield increased as compared to control (13\% to $23 \%$ ) was observed in $\mathrm{T}_{2}(1.0 \mathrm{t}$ gypsum $/ \mathrm{ha}$ ) followed by $\mathrm{T}_{3}(7 \%$ to $15 \%)$. Five years data indicated that application of $1.0 \mathrm{t}$ gypsum/ha was more suitable dose in the area of study. Furthermore, it was also noted that the minimum yield was obtained from farmer practice which confirmed that application of less than recommended doses of fertilizers and other nutrient sources, leads to low wheat yield in district Attock. 


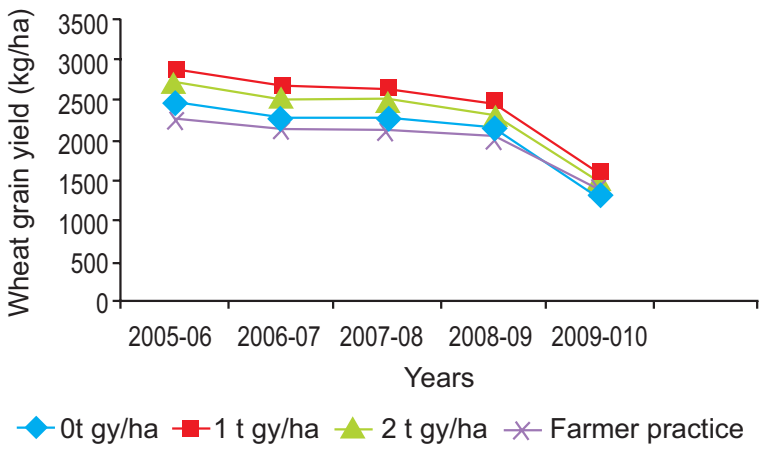

Fig. 3. Effect of gypsum on wheat grain yield (gy).

The response of gypsum application was more profound in the year when relatively lesser rainfall was received, which confirms the hypothesis that gypsum application conserves soil moisture by increasing the infiltration rate and reducing the runoff and soil nutrient losses. Improved physico-chemical properties of soil with the supply of essential nutrients could be the reasons of increase in wheat yield in this study. Shah et al. (2011) concluded that $1.25 \mathrm{t}$ gypsum/ha resulted in higher rate of return (wheat production) compared with $2.5 \mathrm{t}$ gypsum/ha on coarse textured soils under rainfed environment. Rahmatullah et al. (2007) reported that the application of $2.0 \mathrm{t}$ and $4.0 \mathrm{t}$ gypsum/ha increased the wheat yield up to $65.66 \%$ and $25.25 \%$, respectively over the control in medium textured soil while studying the impact of gypsum on soil properties. Rashid et al. (2008) observed $19-46 \%$ increase in wheat grain yield rainfed sandy loam soils by the application of gypsum @ 2.5 t/ha. In present study, it was observed that application of gypsum@1.0 t/ha has performed better/ economical in terms of enhancing wheat grain yield. Application of gypsum on normal soils (free from salinity and sodicity) has shown improved crop yields, which might be due to supplementation of soil with sulphur and calcium. Gypsum also acts as a source of plant nutrients because calcium which is supplied in gypsum acts as a regulator of plant nutrients (Rahmatullah et al., 2007) and also essential for the biochemical mechanisms by which most plant nutrients are absorbed by roots. This mechanism would fail without adequate calcium uptake (Hoeft et al., 1985).

Wheat straw yield. Data in Fig. 4 shows that a considerable increase in wheat straw yield occurred by the application of gypsum and it ranged from $1544 \mathrm{~kg} / \mathrm{ha}$ during this period. The maximum wheat straw yield (6650 kg/ha) was obtained in $T_{2}(1.0 \mathrm{t}$ gypsum/ha) which was $19 \%$ more as compared to control treatment in which no gypsum was added. Banaras et al. (2003) also reported significant increase in wheat grain and straw yield by the application of recommended doses of fertilizers with gypsum, while, Dhillon (2000) reported an increase up to $1.1 \mathrm{t} /$ ha in wheat straw yield by the application of $0.8 \mathrm{t}$ gypsum/ha. It was also noted that the effect of gypsum on wheat straw yield was more profound during the years of least rainfall. But, a considerable significant decrease in the straw yield was observed in 2009-10 probably due to very low rainfall during this year and a disease that affected wheat crop. However, under the normal climatic conditions gypsum application always resulted in higher crop yield as compared to control. This improvement in yield parameters can be attributed to the role of gypsum in decrease volatilization loss of ammonia nitrogen from urea application. Additionally, when sulphate in gypsum is taken up by the plants and metabolized; sulphate is released which is source of oxygen to plant roots. Though a limited source, it may promote the vegetative growth. Similarly the role of gypsum in soil moisture conservation is particular in rainfed areas. Gypsum helps the soil structure to enhance the nutrients supply in the soil solution by lowering the soil $\mathrm{pH}$. This could be a reason for increase in wheat straw yield.

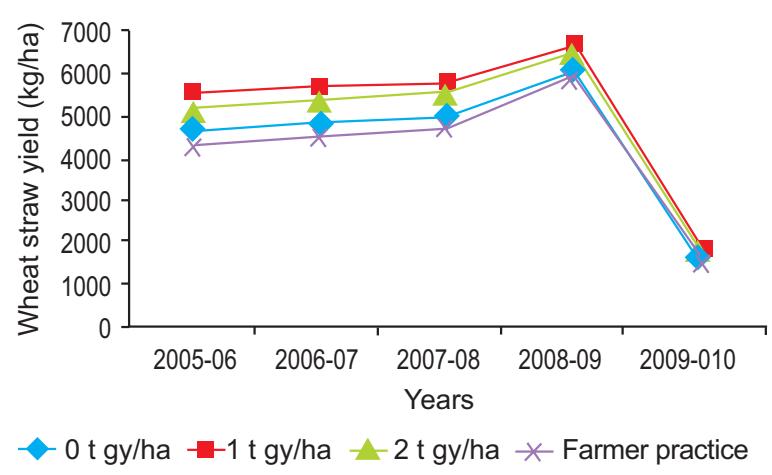

Fig. 4. Effect of gypsum on wheat straw yield.

Soil characteristics. Data regarding the chemical properties of soil before and after the application of gypsum has been presented in Table 1. The data indicates that the gypsum application in general, helped in altering a few soil chemical properties. The data shows that the gypsum application lowered the $\mathrm{pH}$ of the soil from 8.16 to 7.84 . Similar findings have been reported by Chand et al. (1980). Many phenomena may be contributing to this decrease of soil $\mathrm{pH}$. Increased calcium 
Table 1. Comparison of soil characteristics before and after the application of gypsum

\begin{tabular}{|c|c|c|c|c|c|c|c|c|}
\hline \multirow[t]{2}{*}{ Soil parameter } & \multicolumn{4}{|c|}{ Before study $(0-15 \mathrm{~cm})$} & \multicolumn{4}{|c|}{ After study $(0-15 \mathrm{~cm})$} \\
\hline & Kharala-I & Kharala-II & H.Abad-I & H.Abad-II & Kharala-I & Kharala-II & H.Abad-I & H.Abad-II \\
\hline $\mathrm{pH}$ & 8.07 & 8.10 & 8.16 & 8.00 & 7.96 & 7.84 & 8.00 & 7.90 \\
\hline $\mathrm{ECe}(\mathrm{dS} / \mathrm{m})$ & 1.85 & 0.77 & 0.97 & 1.16 & 2.12 & 1.38 & 1.67 & 1.94 \\
\hline O.M (\%) & 0.92 & 0.81 & 0.68 & 0.71 & 0.94 & 0.78 & 0.72 & 0.76 \\
\hline $\begin{array}{l}\text { Extractable P } \\
(\mathrm{mg} / \mathrm{kg})\end{array}$ & 2.00 & 2.50 & 1.80 & 1.50 & 3.10 & 2.94 & 2.70 & 2.40 \\
\hline $\begin{array}{l}\text { Extractable K } \\
(\mathrm{mg} / \mathrm{kg})\end{array}$ & 52.0 & 68.0 & 110.0 & 74.0 & 60.0 & 74.0 & 108.0 & 94.0 \\
\hline B. $\mathrm{D}\left(\mathrm{Mg} \mathrm{M}^{3}\right)$ & 1.61 & 1.58 & 1.62 & 1.60 & 1.53 & 1.47 & 1.42 & 1.40 \\
\hline Textural class & $\begin{array}{l}\text { Sandy } \\
\text { loam }\end{array}$ & $\begin{array}{l}\text { Silty } \\
\text { loam }\end{array}$ & $\begin{array}{l}\text { Sandy } \\
\text { loam }\end{array}$ & $\begin{array}{l}\text { Loamy } \\
\text { sand }\end{array}$ & $\begin{array}{l}\text { Sandy } \\
\text { loam }\end{array}$ & $\begin{array}{l}\text { Silty } \\
\text { loam }\end{array}$ & $\begin{array}{l}\text { Sandy } \\
\text { loam }\end{array}$ & $\begin{array}{l}\text { Loamy } \\
\text { sand }\end{array}$ \\
\hline
\end{tabular}

uptake by roots when gypsum is applied can decrease the $\mathrm{pH}$ of the rhizosphere by increasing the amount of sulphate ions in soil. These sulphate ions can replace hydroxyl ions from some clay lattices. The presence of gypsum in calcareous soils causes a small decrease in $\mathrm{pH}$ through the increased $\mathrm{Ca}^{2+}$ concentration in soil solution which would be expected to decrease the sorption of $\mathrm{P}$. However, the $\mathrm{Ca}^{2+}$ is needed for the formation of calcium phosphates and is expected to increase the amount of phosphate which is immobilized (FAO, 1990). Similarly, reaction of these ions with water is likely to form acid which in turn so reduces the $\mathrm{pH}$ of the medium.

However, gypsum application increased the EC of soil from 0.77 to $2.12 \mathrm{dS} / \mathrm{m}$ because gypsum being readily soluble disturbs buffered solute concentration (EC) in soil to maintain flocculated state. These results are in line with those reported by Rashid et al. (2008). There was no evident effect on O.M (\%) content of the soil. However, gypsum is a good source of calcium that binds/stabilizes soil organic matter to clay in soil which gives stability to soil aggregates. Extractable $\mathrm{P}$ and $\mathrm{K}$ contents were increased from 1.5 to $3.1 \mathrm{mg} / \mathrm{kg}$ and 52 to $108 \mathrm{mg} / \mathrm{kg}$, respectively by the application of gypsum. The increase in $\mathrm{P}$ contents might be due to the fact that gypsum $\left(\mathrm{CaSO}_{4}\right)$ infiltrates with water into soil and the associated calcium improves particle aggregation and dissolved phosphorus retention. An improved soil structure means that resists water erosion better and therefore prevents phosphorus loss. In this way possibility of $\mathrm{P}$ availability to plants increases (Pietola, 2008). It has also been reported by Favaretto et al. (2006) that gypsum promotes the uptake of nutrients by plants $(\mathrm{N}, \mathrm{P}, \mathrm{K}, \mathrm{Ca}, \mathrm{S}, \mathrm{Cu}$, and $\mathrm{Mn})$. Increased concentration of $\mathrm{K}$ in soil after many years of gypsum application could be attributed to the dissolution of $\mathrm{K}$ containing mineral (Moustafa et al., 2010).

Soil moisture conservation. Data presented in Fig. 5 indicates that the soil moisture contents (\%) improved significantly by the application of gypsum in soil during the study period (2005-10). Mean soil moisture contents of selected four locations revealed that minimum soil moisture contents at the depth of $0-15 \mathrm{~cm}$ were $5.02(\%)$ in control at Hafizabad-I and maximum were 17.16(\%) at Kharala-II in the plots where $2.0 \mathrm{t}$ gypsum/ha had been applied. The minimum soil moisture $(6.15 \%)$ was recorded in control treatment at Hafizabad-I and maximum $(18.01 \%)$ was noted at Kharala-II with $2.0 \mathrm{t}$ gypsum application at $15-30 \mathrm{~cm}$. Moisture retention was in the order of Kharala-II $>$ Kharala-I $>$ HafizabadII $>$ Hafizabad-I. Furthermore, it was noted that maximum soil moisture $\left(41.27 \%\right.$ ) was retained in $\mathrm{T}_{3}$ ( $2.0 \mathrm{t}$ gypsum $/ \mathrm{ha}$ ) at both depths. In the farmer practice, soil moisture contents were reduced by $1.67 \%$ at $0-15 \mathrm{~cm}$ depth and $2.69 \%$ at $15-30 \mathrm{~cm}$ depth. The data (Table 1) showes that the soil moisture retention enhanced and bulk density reduced. As soil aggregation

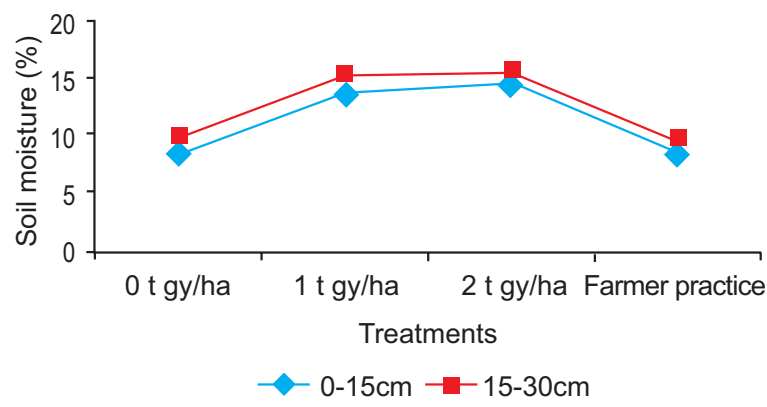

Fig. 5. Effect of gypsum on soil moisture contents. 
improves after gypsum application, it effectively reduces bulk density of the soil (Webster and Nyborg, 1986). Gypsum addition enhances the water infiltration and reduces run off that allows maximum soil moisture conservation (Morin and Winkle, 1996).

\section{Conclusion}

A long term field study (2005-10) was carried out at the farmer's field to evaluate the residual effect of gypsum on soil moisture conservation and on wheat production under rainfed conditions. Gypsum application improved the wheat yield up to $23 \%$ and straw yield up to $19 \%$ by the efficient supply of moisture and improved physicochemical conditions. There was no effect on O.M (\%) content of the soil, however; extractable $\mathrm{P}$ and $\mathrm{K}$ contents were increased from 1.5 to $3.1 \mathrm{mg} / \mathrm{kg}$ and 52 to $108 \mathrm{mg} / \mathrm{kg}$, respectively by the application of gypsum. Gypsum application increases the soil moisture up to $41 \%$ during the study.

\section{References}

Ahmad, M., Raza, F.A., Masud, J., Ali, I. 2006. Ecological assessment of production potential for rangeland vegetation in southern Attock. Pakistan Journal of Agriculture and Social Sciences, 2: 212-215.

Ahmad, N., Hassan, F.U., Belford, R.K. 2009. Effects of soil compaction in the sub-humid cropping environment in Pakistan on uptake of NPK and grain yield in wheat (Triticum aestivum) II: Alleviation. Field Crops Research, 110: 61-68.

AR. 2010. Annual Report, Agriculture Extension Department, District Attock, Pakistan.

Amezketa, E.R., Perez, P.A., Bercero. 2003. Techniques for controlling soil and its effect on corn emergence and production. Spanish Journal of Agriculture Research, 1: 101-110.

Banaras, H., Haq, N.I., Salim, M. 2003. Use of gypsum to increase fertilizer efficiency on normal soils. Asian Journal of Plant Science, 2: 673-676.

Chand, M., Randhawa, N.S., Sinha, M.K. 1980. Effect of gypsum, press mud, fulvic acid and zinc sources on the yield and zinc uptake by rice crop in a salinesodic soil. Plant and Soil, 55: 17-24.

Chaudhry, M.A. 1996. Soil erosion and conservation In: Soil Science, E. Bashir and R. Bantel (eds.), $1^{\text {st }}$ edition, National Book Foundation of Pakistan, Islamabad, Pakistan.

Dhillon, K.S. 2000. Selenium accumulation by sequentially grown wheat and rice as influenced by gypsum application in a seleniferous soil. Plant and Soil, 227: 243-248.

FAO. 1990. Management of Gypsiferous Soils. 81 pp., FAO Soils Bulletin No. 62, FAO, Rome, Italy.

Favaretto, N., Norton, L.D., Joern, B.C., Brouder, S.M., 2006. Gypsum amendment and exchangeable calcium and magnesium affecting phosphorus and nitrogen in runoff. Soil Science Society America Journal, 70: 1788-1796.

Hoeft, R.G., Sawyer, J.E., Vanden-Heuve, R.M., Schmitt, M.A., Brinkman, G.S. 1985. Corn response to sulpher on Illinois soils. Journal of Fertilizer, (Issue 2) 95-104.

Mclean, E.O. 1982. Soil $\mathrm{pH}$ and lime requirement. In: Methods of Soil Analysis, Part 2: Chemical and Microbiological Properties, A. L. Page (ed.), pp. 199-224, $2^{\text {nd }}$ edition (Agronomy), American Society of Agronomy Inc., and Soil Society of America Inc., Madison, Wisconsin, USA.

Morin, J., Winkel, J.V. 1996. The effect of raindrop impact and sheet erosion on infiltration rate and crust formation. Soil Science Society of America Journal, 60: 1223-1227.

Moustafa, A.E., Larry, T.W., Seybold, C.A., Benham, E.C., Philip, J.S., Ferguson, R. 2010. Effect of gypsum addition on solubility of nutrients in soil amended with peat. Soil Science, 175: 162-172.

Pietola, L. 2008. NJF Seminar 401On: Phosphorus Management in Nordic-Baltic Agriculture-Reconciling Productivity and Environmental Protection. NJF Seminar 401, 22-23 September 2008.

Rahmatullah, K, Gurmani, A.R., Khan, M.S., Gurmani, A.H. 2007. Effect of variable rates of gypsum application on wheat yield under Rice-Wheat System. Pakistan Journal of Biological Sciences, 10: 3865-3869.

Rashid, M. 2004. Effect of Different Rates of Qemisoyl and Curasol Polymers on Physical and Chemical Properties of Soil and on Bitter Gourd Yield. M.Sc. (Hons) Thesis, University of Arid Agriculture, Rawalpindi, Pakistan.

Rashid, M., Iqbal, M.N., Akram, M., Ansar, M., Hussain, R. 2008. Role of gypsum in wheat production in rainfed areas. Soil Environment, 27: 166-170.

Rhoades, J.D. 1982. Cation exchange capacity. In: Methods of Soil Analysis, Part 2. Chemical and Microbiological Properties. A. L. Page, R. H. Miller and D. R. Keeney (eds), pp. 149-158, $2^{\text {nd }}$ edition, American Society of Agronomy, Madison, Wisconsin, USA. 
Richards, L.A. (ed.). 1954. Diagnosis and improvement of saline and alkali soils, USDA Handbook No. 60, 160 pp., USA Department of Agriculture, Washington, USA.

Shafiq, M., Rashid, A., Mangrio, A.G. 2005. Agricultural potential soil resources of the Pothwar plateau. Soil Environment, 24: 109-119.

Shafiq, M., Ahmad, B., Amin, R. 1996. Soil moisture contents and crop yields as affected by two elevation positions within the field under rainfed conditions. Pakistan Journal of Soil Sciences, 12: 63-69.

Shah, H., Hussain, K., Akhtar, W., Sharif, M., Majid, A. 2011. Returns from agricultural interventions under changing price scenario: A case of gypsum application for moisture conservation for wheat production under rainfed conditions in Pakistan. World Applied Sciences Journal, 14: 363-368.

Shaheen, A., Shafiq, M. Naeem, M.A., Jilani, G. 2008. Soil characteristics and plant nutrient status in the eroded lands of Fatehjang in the Pothwar plateau of Pakistan. Soil \& Environment, 27: 208-214.

Singer, M.J. 2000. Soil Quality. In: A Hand Book of
Soil Science, M. E. Summer (ed.), pp. 271-298, CRC, Boca, Raton, Fla, USA.

SSP. 1970. Reconnaissance Soil Survey Report: Campbellpur. Soil Survey of Pakistan, Lahore, Pakistan.

Steel, R.G.D., Torrie, J.H., Boston, M.A. 1997. Principles and Procedures of Statistics: A Biometrical Approach, 633 pp., $3^{\text {rd }}$ edition, McGraw Hill Book Company Inc. New York, USA.

Walkley, A., Black, C.A. 1934. An examination of degtjareft methods for determining soil organic matter and proposed modifications of the chromic acid titration method. Soil Science, 37: 29-38.

Watanabe, F.S., Olsen, S.O. 1965. Test of an ascorbic acid method for determination of phosphorus in water and $\mathrm{NaHCO}_{3}$ extracts from soil. Soil Science Society of America Journal, 29: 677-678.

Webster, G.R., Nyborg, M. 1986. Effects of tillage and amendments on yields and selected soil properties of two solonetzic soils. Canadian Journal of Soil Science, 66: 455-470. 